\title{
Influence of Some Boron Compounds on Kraft Pulping of European Black Pine and European Aspen
}

\section{Utjecaj nekih spojeva bora na sulfatni postupak proizvodnje pulpe od drva europskoga crnog bora i europske jasike}

\author{
Original scientific paper • Izvorni znanstveni rad \\ Received-prispjelo: 5. 4. 2017. \\ Accepted-prihvaćeno: 1. 12. 2017. \\ UDK: $630 * 861.311 ; 674.032 .475 .4 ; 674.031623 .234 .2$ \\ doi:10.5552/drind.2017.1723
}

\begin{abstract}
This study investigated the effects of E-48 borax pentahydrate (A), E-67 agro boron (B), and Ground Colemanite $(C)$ on properties of kraft pulp-paper obtained from European black pine and European aspen. The highest screened pulp yield values were determined by adding $8 \%$ B during cooking of both species. The best pulp strength increases were determined by adding $8 \% B$ during cooking of European aspen. Likewise, compared to control samples, the stability of Xylose, Mannose and 4-0-MeGlcA units was increased in European black pine kraft pulp after adding $8 \%$ B. Furthermore, in producing the European aspen pulp, adding of $8 \%$ A during cooking positively affected the total amount of hemicelluloses.
\end{abstract}

Key words: Boron, Kraft pulping, European black pine, European aspen, Paper strength, Hemicelluloses

\begin{abstract}
SAŽETAK • U radu su ispitivani učinci E-48 boraks pentahidrata (A), E-67 agro bora (B) i kolemanita (C) na svojstva papira proizvedenoga od pulpe dobivene sulfatnim postupkom od drva europskoga crnog bora i europske jasike. Najveći prinos pulpe dobiven je dodavanjem $8 \%$ agro bora tijekom kuhanja obiju vrsta drva. Najveća čvrstoća pulpe dobivena je dodavanjem $8 \%$ agro bora tijekom kuhanja europske jasike. Jednako tako, stabilnost ksiloze, manoze i jedinica 4-0-MeGlcA u usporedbi s kontrolnim uzorcima povećana je u pulpi europskoga crnog bora nakon dodavanja $8 \%$ agro bora. Također, dodavanje $8 \%$ boraks pentahidrata tijekom kuhanja drva pri proizvodnji pulpe od drva europske jasike pozitivno je utjecalo na ukupnu količinu hemiceluloza.
\end{abstract}

Ključne riječi: bor, sulfatni postupak proizvodnje pulpe, europski crni bor, europska jasika, čvrstoća papira, hemiceluloze

\footnotetext{
${ }^{1}$ Authors are associate professors at Faculty of Forestry, Bartin University, Bartin, 74100 Turkey. ${ }^{2}$ Author is researcher at Åbo Akademi University, Faculty of Science and Engineering, Wood and Paper Chemistry, Turku, Finland.

Autori su izvanredni profesori Šumarskog fakulteta, Sveučilište u Bartinu, Bartin, Turska. ${ }^{2}$ Autor je znanstvenik Sveučilišta Åbo Academi, Fakultet znanosti i inženjerstva, Kemija drva i papira, Turku, Finska.
} 


\section{INTRODUCTION 1. UVOD}

Turkey has a total boron reserve of 955.3 million tons ( $72.8 \%$ of the world boron reserves) on the basis of $\mathrm{B}_{2} \mathrm{O}_{3}$ content. Also, it is one of the biggest producers of boron compound in the world ( $47 \%$ of boron market). The annual boron compound production of Turkey is 1.95 million tons. The important boron minerals in Turkey are tincal $\left(\mathrm{Na}_{2} \mathrm{O} \cdot 2 \mathrm{~B}_{2} \mathrm{O}_{3} \cdot 10 \mathrm{H}_{2} \mathrm{O}\right)$, colemanite $\left(2 \mathrm{CaO} \cdot 3 \mathrm{~B}_{2} \mathrm{O}_{3} \cdot 5 \mathrm{H}_{2} \mathrm{O}\right)$ and ulexite $\left(\mathrm{Na}_{2} \mathrm{O} \cdot 2 \mathrm{CaO} \cdot 5 \mathrm{~B}_{2} \mathrm{O}_{3}\right.$ $\left.\cdot 16 \mathrm{H}_{2} \mathrm{O}\right)$ (Eti Mine, 2013).

Since the development of alkaline pulping in 1851, many researchers have tried to increase the pulp yield owing to delignification with a minimum carbohydrate loss. As known, polyoses (hemicelluloses) have some effect on physical and mechanical properties of pulp and paper (Bai et al., 2012; Hu et al., 2013). The pulp yield losses can be prevented by reduction or oxidation of carbohydrate reducing end. For this purpose, cooking liquor additives such as sodium borohydride (Hartler, 1959; Aurell and Hartler, 1963; Diaconescu and Petrovan, 1976; Akgül et al., 2007; Istek and Ozkan, 2008; Tutus et al., 2010; Gulsoy and Eroglu, 2011; Gumuskaya et al., 2011) anthraquinone (Jakate et al., 1981; Manji, 1996; Atik, 2002; Akgul and Tozluoglu, 2009; Kamyar et al., 2014; Gulsoy et al., 2015) and polysulfide (Pekkala, 1982; Jiang, 1994; MacLeod et al., 2002; Paanenen and Sixta, 2015) were extensively studied. However, there are no published data related to effects of E-48 $\left(\mathrm{Na}_{2} \mathrm{~B}_{4} \mathrm{O}_{7} \cdot 5 \mathrm{H}_{2} \mathrm{O}\right)$, E-67 $\left(\mathrm{Na}_{2} \mathrm{~B}_{8} \mathrm{O}_{13} \cdot 4 \mathrm{H}_{2} \mathrm{O}\right)$, and $\mathrm{GCol}\left(\mathrm{CaB}_{3} \mathrm{O}_{4}(\mathrm{OH})_{3}-\mathrm{H}_{2} \mathrm{O}\right)$ on pulp and paper properties.

In this scope, European black pine and European aspen, two wide spread species, are used with different ratios $(4 \%$ and $8 \%$ ) of $A, B$, and $C$ to determine the effects of adding boron compounds on kraft pulp and paper properties, as well as on the composition of polyoses.

\section{MATERIALI AND METHODS 2. MATERIJALI I METODE}

\subsection{Materials}

2.1. Materijali

Freshly cut European black pine (Pinus nigra Arn.) and European aspen (Populus tremula L.) from the Bartin province of Turkey were debarked and chipped into $3.0-1.5-0.5 \mathrm{~cm}$. Chips were air dried and stored with less than $15 \%$ moisture content until used for the pulping process. Samples used for polyoses analysis were stored in a cold and dark place. A (Na$\left.{ }_{2} \mathrm{~B}_{4} \mathrm{O}_{7} \cdot 5 \mathrm{H}_{2} \mathrm{O}\right)$, B $\left(\mathrm{Na}_{2} \mathrm{~B}_{8} \mathrm{O}_{13} \cdot 4 \mathrm{H}_{2} \mathrm{O}\right)$, and $\mathrm{C}$ $\left(\mathrm{CaB}_{3} \mathrm{O}_{4}(\mathrm{OH})_{3}-\mathrm{H}_{2} \mathrm{O}\right)$ used in this study were obtained from Eti Mine, Turkey. Boron oxide $\left(\mathrm{B}_{2} \mathrm{O}_{3}\right)$ contents of $\mathrm{A}, \mathrm{B}$, and $\mathrm{C}$ were $48 \%, 67 \%$, and $40 \%$, respectively.

\subsection{Methods}

2.2. Metode

The kraft cooking conditions of European black pine and European aspen are summarized in Table 1. For both species, the $4 \%$ and $8 \%$ (oven-dried wood) boron compounds in powder form were added to kraft cooking liquor. A and B were dissolved, while $\mathrm{C}$ was partially dissolved in the cooking liquor at room temperature. Under the same cooking conditions, the boron compound-free kraft cooking was also done as control. The air dried chips equivalent to $650 \mathrm{~g}$ oven dried for each cooking experiment were cooked in a 15 L electrically heated laboratory cylindrical type rotary digester. After cooking, pulps were washed with tap water to remove residual liquor. After washing, pulps were disintegrated and screened on $0.15 \mathrm{~mm}$ slot screen (TAPPI T 275). Pulps were then beaten to $25^{\circ} \mathrm{SR}$ in a Valley Beater (TAPPI T 200). Kappa number, screened yield, viscosity, and freeness of pulps were determined using TAPPI T 236, TAPPI T 210, SCANCM 15-62 and ISO 5267-1, respectively.

Table 1 Kraft cooking conditions of European black pine and European aspen

Tablica 1. Uvjeti kuhanja pri sulfatnom postupku proizvodnje pulpe od drva europskoga crnog bora i europske jasike

\begin{tabular}{|c|c|c|c|c|c|c|}
\hline \multirow[t]{2}{*}{ Conditions / Uvjeti } & \multicolumn{3}{|c|}{$\begin{array}{c}\text { European black pine } \\
\text { Europski crni bor }\end{array}$} & \multicolumn{3}{|c|}{$\begin{array}{l}\text { European aspen } \\
\text { Europska jasika }\end{array}$} \\
\hline & $\mathbf{A}$ & B & C & A & B & C \\
\hline Active alkali / aktivna lužina, \% & \multicolumn{3}{|c|}{20} & \multicolumn{3}{|c|}{16} \\
\hline Sulfidity / sulfidnost, $\%$ & \multicolumn{3}{|c|}{25} & \multicolumn{3}{|c|}{20} \\
\hline A ratio / udjel $A, \%$ & $4-8$ & - & - & $4-8$ & - & - \\
\hline B ratio / udjel $B, \%$ & - & $4-8$ & - & - & $4-8$ & - \\
\hline $\mathrm{C}$ ratio / udjel $C, \%$ & - & - & $4-8$ & - & - & $4-8$ \\
\hline Temperature / temperatura,${ }^{\circ} \mathbf{C}$ & \multicolumn{6}{|c|}{170} \\
\hline $\begin{array}{l}\text { Time to max. temperature, } \min \\
\text { vrijeme do maks. temperature, } \min \end{array}$ & \multicolumn{6}{|c|}{90} \\
\hline $\begin{array}{l}\text { Time at max. temperature, } \min \\
\text { vrijeme na maks. temperaturi, } \min \end{array}$ & \multicolumn{6}{|c|}{60} \\
\hline $\begin{array}{l}\text { Total cooking time, min } \\
\text { ukupno vrijeme kuhanja, min }\end{array}$ & \multicolumn{6}{|c|}{150} \\
\hline \begin{tabular}{|l} 
Liquor/chip ratio \\
omjer otapala $i$ sječke
\end{tabular} & \multicolumn{6}{|c|}{$4 / 1$} \\
\hline
\end{tabular}


$75 \mathrm{~g} / \mathrm{m}^{2}$ handsheets made by Rapid-Kothen Sheet Former (ISO 5269-2) were conditioned (TAPPI T 402). Tensile properties (tensile index, stretch, and TEA), burst index tear index and brightness of the handsheets were measured according to TAPPI standards $\mathrm{T} 494, \mathrm{~T}$ 403, $\mathrm{T} 414$, and $\mathrm{T} 525$, respectively. The data of handsheet properties for each cooking were statistically analyzed using analyses of variance (ANOVAs) and Duncan test at a $95 \%$ confidence level. The same lower case letter in Figure 5-9 denotes that the difference in the mean values of properties among the compared groups was not statistically significant $(P>0.05)$.

The remaining polyoses (Hemicelluloses) after the pulping process were determined by acid methanolysis (Sunderberg et al., 1998). Mean values are presented in Table 4.

\section{RESULTS AND DISCUSSION}

\section{REZULTATI I RASPRAVA}

The kappa number of pulp indicates the degree of delignification in cooking. In the European black pine pulp samples, $\mathrm{B}$ additions caused the increase of the kappa number, while $\mathrm{A}$ and $\mathrm{C}$ additions led to the decrease of the kappa number compared to control pulp (Figure 1). The lowest and highest kappa numbers, 36.1 and 63.4, respectively, were observed when $4 \% \mathrm{~A}$ and $8 \% \mathrm{~B}$ were added to cooking. In the European aspen pulp samples, the kappa number decreased with the addition of $\mathrm{A}$ (Figure 1). However, the addition of $\mathrm{B}$ and $\mathrm{C}$ to the cooking liquor caused an increase in the kappa number. The lowest and highest kappa numbers, 14.6 and 37.9 respectively, were observed when $4 \% \mathrm{~A}$ and $8 \% \mathrm{C}$ were added to the cooking. These results showed that the addition of A accelerates the delignification, while the addition of $\mathrm{B}$ has a negative effect on the kappa number of pulps. On the other hand, the addition of $\mathrm{C}$ seems not to affect delignification rate of European black pine, whereas it clearly decreases delignification rate of European aspen.

The pulp viscosity is an indicator of degree of polymerization (DP) of polysaccharides (especially cellulose). Therefore, the degradation of polysaccharides during cooking results in a decrease in pulp viscosity. In the European black pine pulp samples, the addition of $\mathrm{A}$ and $\mathrm{C}$ resulted in pulp viscosity losses. However, the addition of B caused an increase compared to control pulp. The lowest and highest pulp viscosity values of $907 \mathrm{~cm}^{3} / \mathrm{g}$ and $1070 \mathrm{~cm}^{3} / \mathrm{g}$, respectively, were observed when $8 \% \mathrm{~A}$ and $8 \% \mathrm{~B}$ were added to the cooking. In the European aspen pulp samples, pulp viscosity increased with the addition of all boron compounds. The addition of B to the cooking liquor of both species led to the increase of viscosity. This result can be explained by higher kappa number and higher reject ratio of these pulps compared to control samples (Table 2 and Table 3). Also, higher polyoses retention during cooking causes higher pulp viscosity. With the exception of $4 \%$ B in European black pine, as can be seen in Table 4 , the addition of $8 \% \mathrm{~B}$ to the cooking resulted in the highest viscosity values with the highest concentration of polyoses $(119 \mathrm{mg} / \mathrm{g})$.

The brightness of handsheets obtained from boron compounds-added pulps of European black pine was found to increase with the addition of $\mathrm{A}$ and $\mathrm{C}$ ( Table 2). However, the addition of B to the cooking liquor caused the decrease in handsheet brightness. This results can be explained by lower kappa number of A and
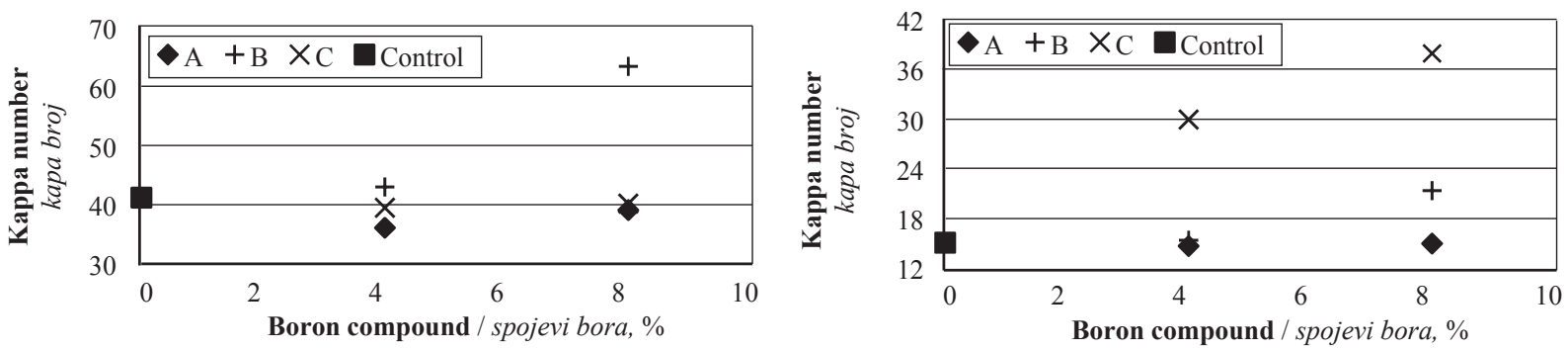

Figure 1 Effect of boron compounds on kappa number of pine (a) and aspen (b) pulps

Slika 1. Utjecaj spojeva bora na kapa broj pulpe proizvedene od drva (a) bora i (b) jasike

Table 2 Pulp properties of control and boron compound-added pulps of European black pine

Tablica 2. Svojstva pulpe proizvedene od drva europskoga crnog bora, kontrolnog uzorka pulpe i pulpe s dodatkom spojeva bora

\begin{tabular}{|l|c|c|c|c|c|c|}
\hline $\begin{array}{l}\text { Cooking } \\
\text { Kuhanje }\end{array}$ & $\begin{array}{c}\text { Screened yield } \\
\text { Prinos prosijavanja } \\
\%\end{array}$ & $\begin{array}{c}\text { Reject } \\
\text { Skart prosijavanja } \\
\%\end{array}$ & $\begin{array}{c}\text { Total yield } \\
\text { Ukupni prinos } \\
\%\end{array}$ & $\begin{array}{c}\text { Kappa } \\
\text { number } \\
\text { Kapa broj }\end{array}$ & $\begin{array}{c}\text { Viscosity } \\
\text { Viskoznost } \\
\mathrm{cm}^{3} / \mathrm{g}\end{array}$ & $\begin{array}{c}\text { Brightness } \\
\text { Sjajnost } \\
\%\end{array}$ \\
\hline Control / kontrolni uzorak & 49.0 & 0.5 & 49.5 & 41.2 & 959 & 19.2 \\
\hline $4 \% \mathrm{~A}$ & 49.9 & 0.5 & 50.4 & 36.1 & 952 & 19.6 \\
\hline $8 \% \mathrm{~A}$ & 50.8 & 0.3 & 51.1 & 39.1 & 907 & 20.1 \\
\hline Control / kontrolni uzorak & 49.0 & 0.5 & 49.5 & 41.2 & 959 & 19.2 \\
\hline 4\% B & 50.5 & 0.6 & 51.1 & 43.0 & 1002 & 18.9 \\
\hline $8 \% \mathrm{~B}$ & 54.1 & 1.6 & 55.7 & 63.4 & 1070 & 17.5 \\
\hline Control / kontrolni uzorak & 49.0 & 0.5 & 49.5 & 41.2 & 959 & 19.2 \\
\hline $4 \% \mathrm{C}$ & 50.3 & 0.6 & 50.9 & 39.5 & 936 & 20.2 \\
\hline $8 \% \mathrm{C}$ & 51.0 & 0.6 & 51.6 & 40.2 & 949 & 20.5 \\
\hline
\end{tabular}


Table 3 Pulp properties of control and boron compound-added pulps of European aspen

Tablica 3. Svojstva pulpe proizvedene od drva europske jasike, kontrolnog uzorka pulpe i pulpe s dodatkom spojeva bora

\begin{tabular}{|l|c|c|c|c|c|c|}
\hline $\begin{array}{l}\text { Cooking } \\
\text { Kuhanje }\end{array}$ & $\begin{array}{c}\text { Screened yield } \\
\text { Prinos prosijavanja } \\
\%\end{array}$ & $\begin{array}{c}\text { Reject } \\
\text { Skart prosijavanja } \\
\%\end{array}$ & $\begin{array}{c}\text { Total yield } \\
\text { Ukupni prinos } \\
\%\end{array}$ & $\begin{array}{c}\text { Kappa } \\
\text { number } \\
\text { Kapa broj }\end{array}$ & $\begin{array}{c}\text { Viscosity } \\
\text { Viskoznost } \\
\mathrm{cm}^{3 / g}\end{array}$ & $\begin{array}{c}\text { Brightness } \\
\text { Sjajnost } \\
\%\end{array}$ \\
\hline Control / kontrolni uzorak & 53.6 & 0.2 & 53.8 & 15.0 & 959 & 26.8 \\
\hline $4 \% \mathrm{~A}$ & 55.6 & 0.3 & 55.9 & 14.6 & 1002 & 26.0 \\
\hline $8 \% \mathrm{~A}$ & 56.2 & 0.5 & 56.7 & 14.9 & 1056 & 25.8 \\
\hline Control / kontrolni uzorak & 53.6 & 0.2 & 53.8 & 15.0 & 959 & 26.8 \\
\hline 4\% B & 55.9 & 0.6 & 56.5 & 15.3 & 1012 & 25.4 \\
\hline 8\% B & 56.4 & 1.9 & 58.3 & 21.3 & 1092 & 23.2 \\
\hline Control / kontrolni uzorak & 53.6 & 0.2 & 53.8 & 15.0 & 959 & 26.8 \\
\hline $4 \% \mathrm{C}$ & 52.9 & 3.9 & 56.8 & 29.9 & 959 & 20.0 \\
\hline $8 \% \mathrm{C}$ & 46.3 & 16.8 & 63.1 & 37.9 & 1134 & 16.1 \\
\hline
\end{tabular}

C pulps and higher kappa number of B pulps than that of the control pulp. The highest brightness increase of $6.8 \%$ was found in the pulp when $8 \% \mathrm{C}$ was added. In the European aspen samples, brightness of handsheets decreased with the addition of all boron compounds (Table 3). The highest brightness loss of $39.9 \%$ was determined in the pulp when $8 \% \mathrm{C}$ was added. These results show that the effect of $\mathrm{A}$ and $\mathrm{C}$ on brightness of handsheets depends on tree species.

For many years, digester additives such as anthraquinone (Gulsoy et al., 2015), polysulfur, and sodium borohydride (Gulsoy and Eroglu, 2011) have been used to increase relatively low pulp yield of kraft method as shown in many studies. The screened pulp yield of boron compound-added pulps in both species increased with the increase of the added boron compound ratio (Figure 2). The pulp yield increases can be explained by the prevention of degradation reactions, such as peeling and alkaline hydrolysis, when boron compound was added during cooking. The highest screened yield in European black pine and European aspen was 54.1\% and 56.4 $\%$, respectively, when $8 \% \mathrm{~B}$ was added to the pulp of both species. However, the screened pulp yield of European aspen decreased with the addition of $\mathrm{C}$, because the defibration point has not been reached. On the other hand, the total yield of pulps increased with the addition of all boron compounds to both species. The highest total yield values of European black pine and European aspen samples were $55.7 \%$ and 58.3 $\%$, respectively, when $8 \% \mathrm{~B}$ was added to the pulp of both species.

When comparing the screened yield vs kappa No, boron addition clearly results in increased yield at a given kappa number for softwood (Figure 3a). For hardwood, the yield increases when A and B are added. Addition of $\mathrm{C}$ decreases the yield (Figure $3 \mathrm{~b}$ ). However, this is because the defibration point has not been reached, and the reject content is much higher when cooking with $\mathrm{C}$.
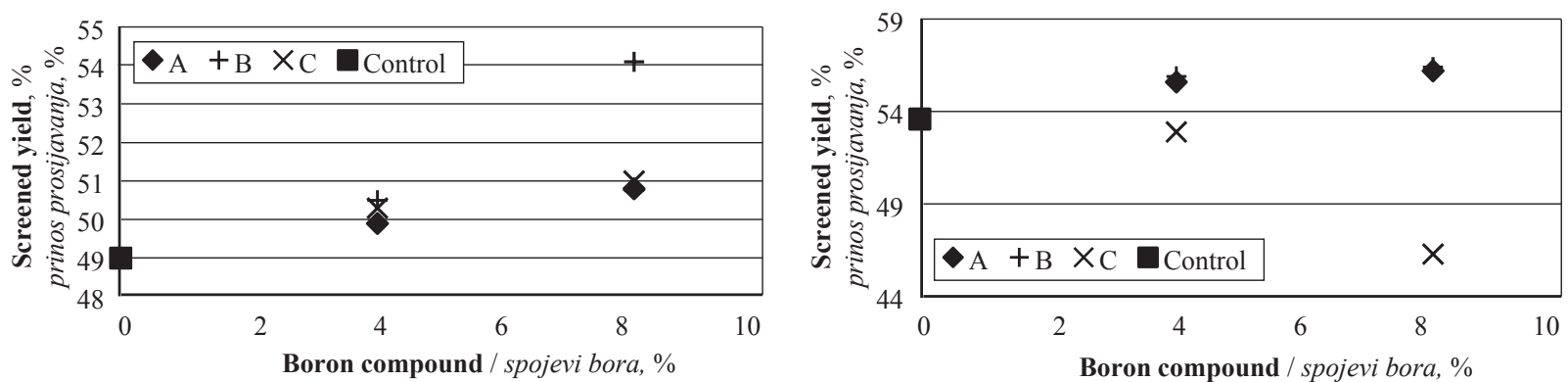

Figure 2 Effect of boron compounds on screened yield of pine (a) and aspen (b) pulps Slika 2. Utjecaj spojeva bora na prinos prosijavanja pulpe od drva (a) bora i (b) jasike
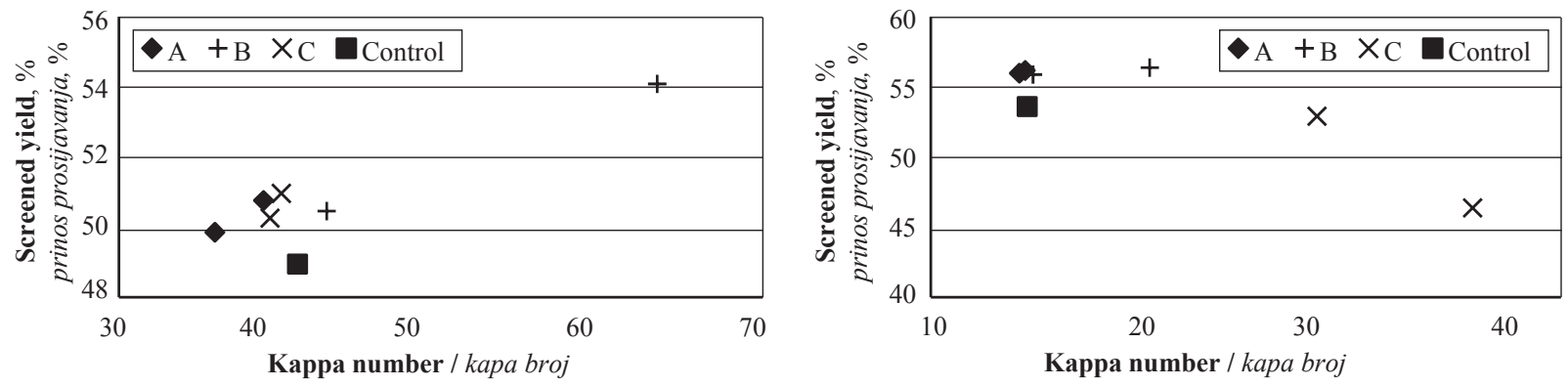

Figure 3 Relationship between screened yield and kappa number of pine (a) and aspen (b) pulps

Slika 3. Odnos između prinosa prosijavanja i kapa broja pulpe od drva (a) bora i (b) jasike 

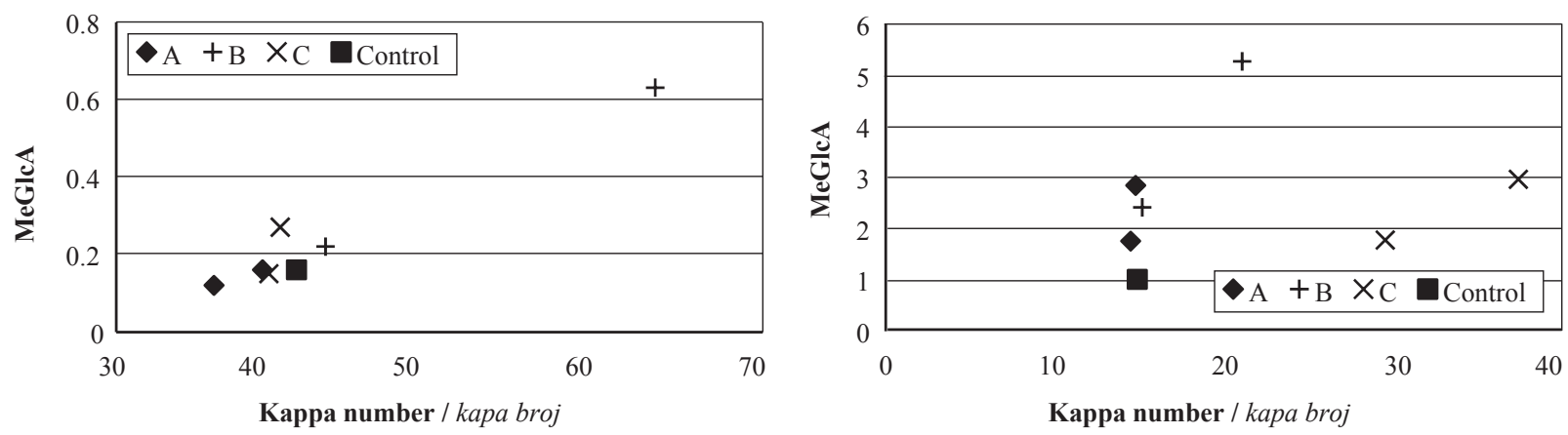

Figure 4 Relationship between MeGlcA and kappa number of pine (a) and aspen (b) pulps

Slika 4. Odnos između količine MeGlcA i kapa broja pulpe od drva (a) bora i b) jasike

The reject ratio of pulp provides information related to the pulping efficiency and penetration of the cooking liquor into wood chips. In the European black pine samples, the addition of $\mathrm{A}$ caused the decrease of reject ratio, while the addition of $\mathrm{B}$ and $\mathrm{C}$ resulted in the increase of reject ratio compared to control pulp. In the European aspen samples, the reject ratio of the pulp increased with the addition of all boron compounds. The highest reject ratios of European black pine and European aspen samples were $1.6 \%$ and $16.8 \%$ when $8 \% \mathrm{~B}$ and $8 \% \mathrm{C}$ were added to the pulp, respectively. High reject ratio of $3.9 \%$ was also determined when $4 \% \mathrm{C}$ was added to the pulp of European aspen. These results showed that the addition of $\mathrm{C}$ to the cooking liquor of European aspen samples slows the penetration of the cooking liquor into wood chips. In this case, longer cooking time is required to reach defibration point.

During the kraft pulping process, $40 \%$ of European aspen and $50 \%$ of European black pine polyoses were lost. Boron compounds, B (4-8 \%) and A (8 \%), slightly improved the stability of polyoses. As known, in softwoods Mannose are dominant units (20-25\%), and in hardwoods Xylose (15-30\%) are dominant units. This can also clearly be seen from Table 4 . The effect of boron compounds on the stability of these units showed varieties. Except $\mathrm{C}$ and $4 \% \mathrm{~B}$, all boron compounds had a positive effect on the Mannose units in European black pine. The $8 \%$ B showed a $15 \%$ increase in the stability. Likewise, in the European aspen boron compounds, $4-8 \% \mathrm{~B}$ and $8 \% \mathrm{~A}$ enhance the Xylose stability. Hexuronic acids (Glucoronic and Galacturonic acids), except 4-0-MeGlcA, were totally destroyed during the pulping process. However, the addition of boron compounds increased the stability of 4-0-MeGlcA, especially in the aspen pulp, e.g. B increased acid by $28 \%$ compared to the control sample.

When boron compounds are added to hardwood, higher amounts of MeGlcA groups are created, although xylan remains more or less the same. For softwood, the MeGlcA content seems to depend on the degree of delignification (Figure 4a), which is not the case for hardwood (Figure $4 b$ ).

All boron compounds added to kraft cooking liquor of European black pine chips led to the decrease in strength properties of the resulting pulp (Figure 5-9). The highest and lowest strength losses were determined when $8 \% \mathrm{C}$ and $4 \% \mathrm{~B}$ were added to the pulp, respectively. The strength properties of boron compounds-added pulps of European aspen were determined to be higher than those of control pulp (Figure 5-9). The highest strength increases were determined in the pulp when $8 \% \mathrm{~B}$ was added.

Tensile index of handsheets in European black pine samples decreased with the addition of boron compounds, while tensile index of handsheets in European aspen samples increased (Figure 5). In the European black pine samples, the highest tensile index loss of $13.8 \%$ (from $102.6 \mathrm{~N} \cdot \mathrm{m} / \mathrm{g}$ to $88.4 \mathrm{~N} \cdot \mathrm{m} / \mathrm{g}$ ) was determined when $8 \% \mathrm{C}$ was added to the pulp. On the other hand, tensile index losses caused by the addition of $4 \%$ A to the pulp were not statistically significant $(P>0.05)$. Furthermore, tensile index losses increased with increasing the addition of boron compound ratios. In the European aspen, the highest tensile index increase of $24.0 \%$ (from $70.1 \mathrm{~N} \cdot \mathrm{m} / \mathrm{g}$ to $86.9 \mathrm{~N} \cdot \mathrm{m} / \mathrm{g}$ ) was found when $8 \% \mathrm{~B}$ was added to the pulp. Also, tensile index increases correlated positively with the increasing addition of boron compound ratios, excluding $\mathrm{C}$ additions (Figure 5). This result can be explained by the increase of the hemicellulose content of the pulp obtained when $8 \% \mathrm{~B}$ was added to the cooking liquor. The strength improving effect of hemicellulose is attributed to its high hydrophilic properties. Due to the high affinity for water, hemicellulose improves swelling of the fiber. Thus, fiber flexibility increases with increasing the hemicellulose content (Shin and Stromberg, 2006; Danielsson, 2007). Flexible fibers enable larger contact areas with neighboring fibers. This results in stronger inter-fiber bonds (Forsström et al., 2005), and higher tensile index (Santos et al., 2008).

The stretch ratio of handsheets obtained from boron compounds-added pulps of European black pine was determined to be lower than that of the control pulp $(P<0.05)$. The highest stretch loss of $7.5 \%$ (from $\% 2.28$ to $\% 2.11$ ) was determined when $8 \% \mathrm{C}$ was added to the pulp. In the European aspen, stretch ratio of handsheets increased with the addition of boron compounds, except for pulps where $\mathrm{C}$ was added. The highest stretch increase of $6.3 \%$ (from \% 2.08 to $\%$ 2.21) was found in the pulp when $8 \% \mathrm{~B}$ was added. However, stretch ratio of handsheets decreased by 9.1 $\%$ with the addition of $8 \% \mathrm{C}$ (Figure 6 ).

As can be seen in Figure 7, TEA of handsheets in European black pine samples decreased with the addi- 

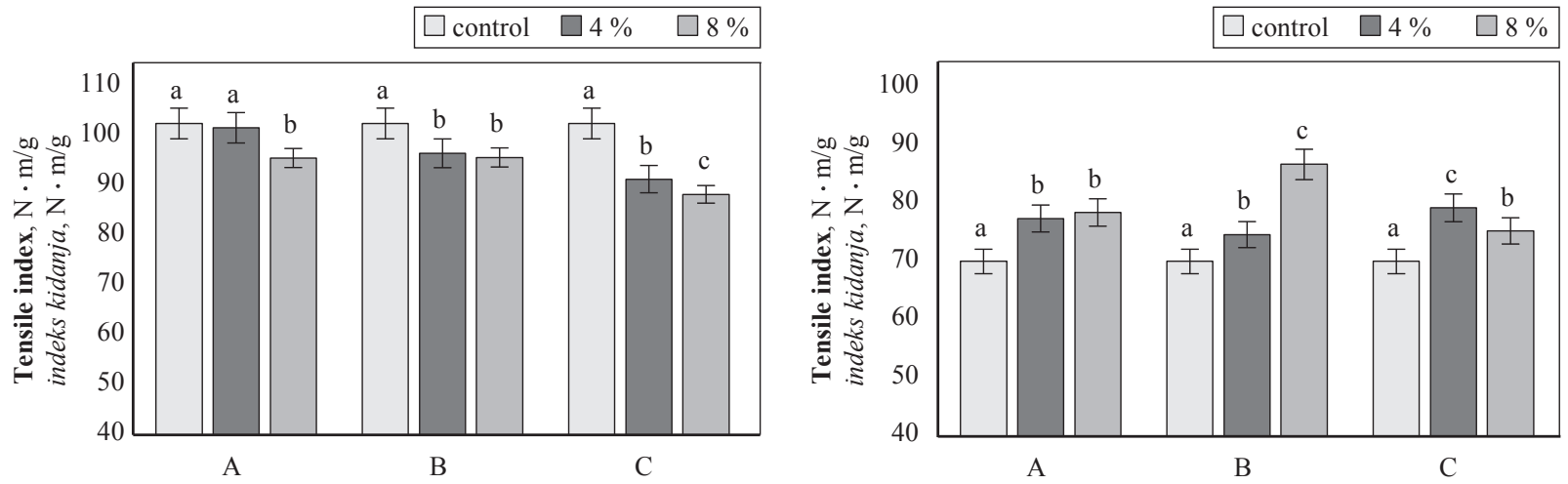

Figure 5 Effect of boron compounds on tensile index of pine (a) and aspen (b) handsheets Slika 5. Utjecaj spojeva bora na indeks kidanja uzoraka papira od (a) bora i (b) jasike
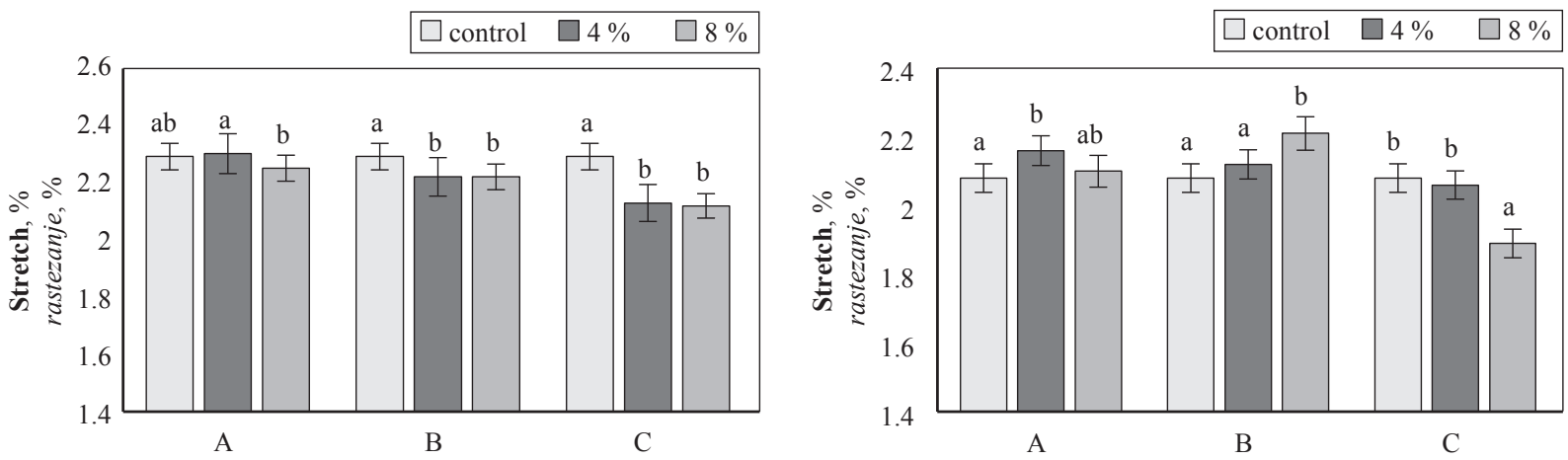

Figure 6 Effect of boron compounds on stretch of pine (a) and aspen (b) handsheets

Slika 6. Utjecaj spojeva bora na rastezanje uzoraka papira od (a) bora i (b) jasike

tion of boron compounds, while TEA of handsheets in European aspen samples increased, except when $8 \% \mathrm{C}$ was added to the pulp (6.5\% TEA loss). In the European black pine samples, the highest TEA loss of $18.6 \%$ (from $119.3 \mathrm{~J} / \mathrm{m}^{2}$ to $97.1 \mathrm{~J} / \mathrm{m}^{2}$ ) was found when $8 \% \mathrm{C}$ was added to the pulp. On the other hand, TEA losses in the pulp when $4 \%$ A was added were not statistically significant $(P>0.05)$. In the European aspen, the highest TEA increase of $31.9 \%$ (from $78.1 \mathrm{~J} / \mathrm{m}^{2}$ to $103.0 \mathrm{~J} / \mathrm{m}^{2}$ ) was found when $8 \% \mathrm{~B}$ was added to the pulp.

The effects of boron compounds on tear index of handsheets are shown in Figure 8. It was observed that the tear index of handsheets of both species increased significantly $(P<0.05)$ with the addition of boron compounds, except for the pulp of European black pine when $\mathrm{C}$ was added. In European black pine and European aspen, the highest tear index increases of $8.3 \%$ (from $12.1 \mathrm{mN} \cdot \mathrm{m}^{2} / \mathrm{g}$ to $13.1 \mathrm{mN} \cdot \mathrm{m}^{2} / \mathrm{g}$ ) and $9.6 \%$ (from $7.3 \mathrm{mN} \cdot \mathrm{m}^{2} / \mathrm{g}$ to $8.0 \mathrm{mN} \cdot \mathrm{m}^{2} / \mathrm{g}$ ), respectively, were found when $8 \%$ A was added to the pulp. Xylan stability, known to have positive influence on tear index, could be the effect of this increase (Schwikal et al., 2011; Tavast et al., 2014).

The correlation between the addition of boron compounds and burst index of handsheets is presented in Figure 9. In European black pine, burst index of handsheets decreased when boron compounds were added to the cooking liquor. However, burst index losses were not statistically significant $(P>0.05)$ when $4 \%$ A was added to the pulp. The highest burst index loss
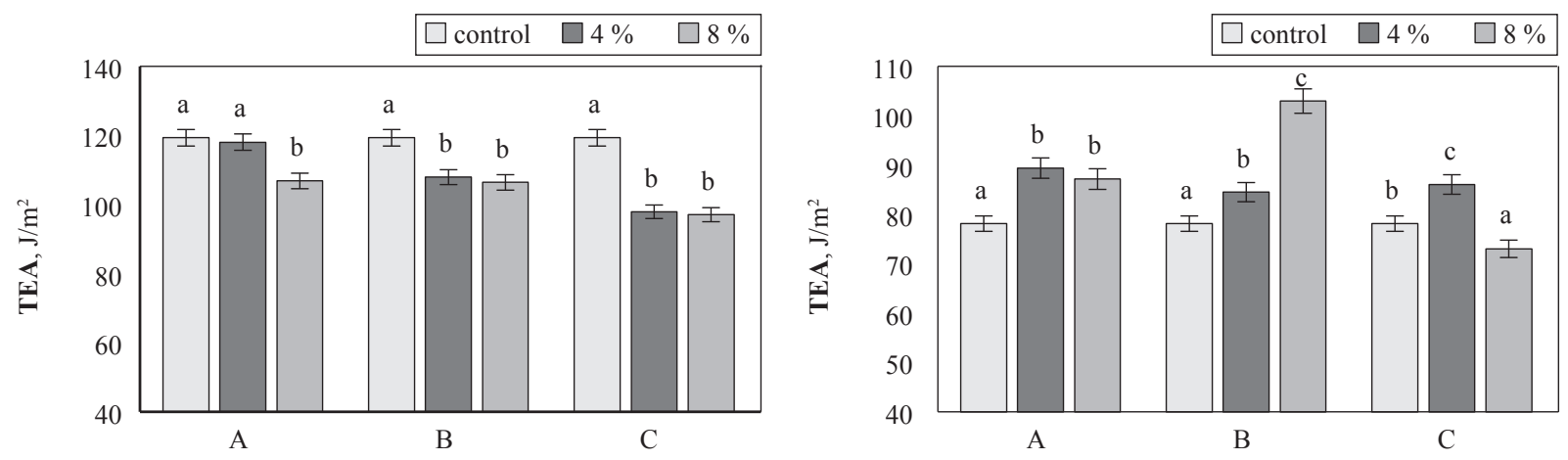

Figure 7 Effect of boron compounds on TEA of pine (a) and aspen (b) handsheets

Slika 7. Utjecaj spojeva bora na prekidnu jakost uzoraka papira od (a) bora i (b) jasike 

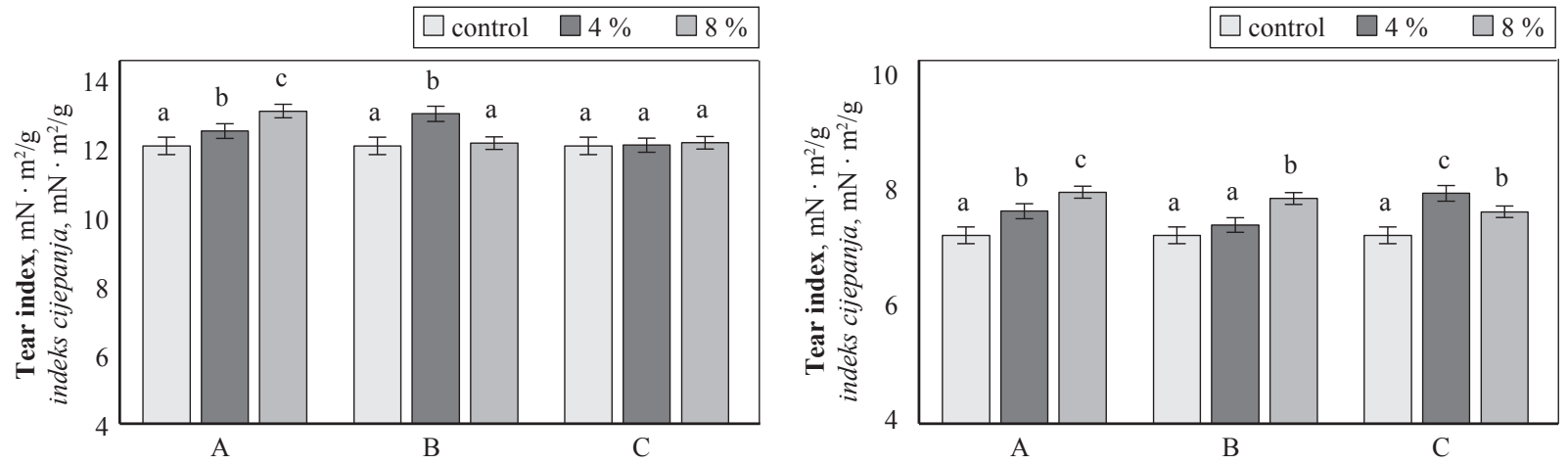

Figure 8 Effect of boron compounds on tear index of pine (a) and aspen (b) handsheets

Slika 8. Utjecaj spojeva bora na indeks cijepanja uzoraka papira od (a) bora i (b) jasike
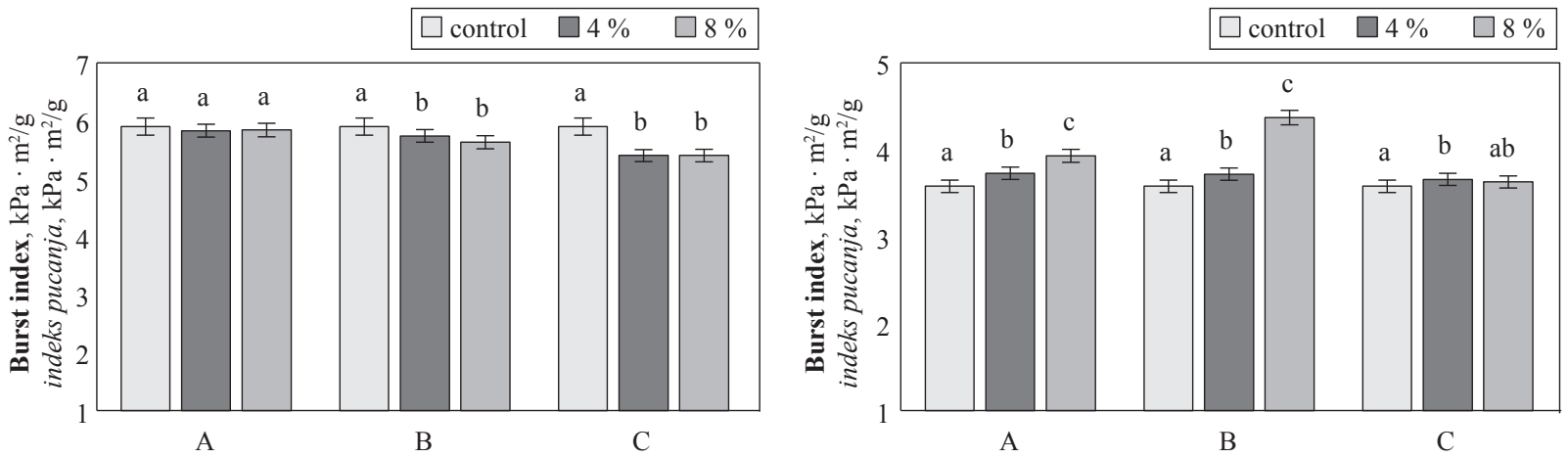

Figure 9 Effect of boron compounds on burst index of pine (a) and aspen (b) handsheets

Slika 9. Utjecaj spojeva bora na indeks pucanja uzoraka papira od (a) bora i (b) jasike

of $8.5 \%$ (from $5.90 \mathrm{kPa} \cdot \mathrm{m}^{2} / \mathrm{g}$ to $5.40 \mathrm{kPa} \cdot \mathrm{m}^{2} / \mathrm{g}$ ) was determined when $4 \%$ and $8 \% \mathrm{C}$ was added to the pulp. In European aspen, burst index of handsheets significantly increased $(\mathrm{P}<0.05)$ with the addition of boron compounds (Figure 9). The highest burst index in- crease of $22.1 \%$ (from $3.58 \mathrm{kPa} \cdot \mathrm{m}^{2} / \mathrm{g}$ to $4.37 \mathrm{kPa} \cdot \mathrm{m}^{2} / \mathrm{g}$ ) was found when $8 \% \mathrm{~B}$ was added to the pulp. The results are compatible with Table 4. Strength increases can also be attributed to more hemicellulose retention during cooking (Molin and Teder, 2002).

Table 4 Amount of sugar units in wood and pulps of European black pine and European aspen (mg/g dry sample).

Tablica 4. Količina jedinica šećera u drvu i pulpi europskoga crnog bora i europske jasike

\begin{tabular}{|l|c|c|c|c|c|c|c|c|c|c|}
\hline \multicolumn{1}{|c}{$\begin{array}{c}\text { Samples } \\
\text { Uzorci }\end{array}$} & Ara & Rha & Xyl & Man & Gal & Glc & GlcA & GalA & 4-0-MeGlcA & Total \\
\hline Black Pine wood / drvo crnog bora & 15.5 & 1.77 & 49.5 & 96.4 & 19.1 & 29.1 & 3.89 & 10.5 & 8.60 & 234 \\
\hline $\begin{array}{l}\text { Black Pine pulp control } \\
\text { kontrolni uzorak pulpe od crnoga bora }\end{array}$ & 6.05 & 0.08 & 35.1 & 33.2 & 6.44 & 37.6 & 0 & 0 & 0.16 & 119 \\
\hline Black Pine 4 \% A / crni bor 4\% A & 4.69 & 0.04 & 35.3 & 33.6 & 4.74 & 34.2 & 0 & 0 & 0.12 & 113 \\
\hline Black Pine 8 \% A / crni bor 8\% A & 4.32 & 0.03 & 37.1 & 33.8 & 4.19 & 33.3 & 0 & 0 & 0.16 & 113 \\
\hline Black Pine 4 \% B / crni bor 4\% B & 4.76 & 0.07 & 36.0 & 32.8 & 4.74 & 32.3 & 0 & 0 & 0.22 & 111 \\
\hline Black Pine 8 \% B / crni bor 8\% B & 5.94 & 0.04 & 38.6 & 38.1 & 5.31 & 30.5 & 0 & 0 & 0.63 & 119 \\
\hline Black Pine 4 \% C / crni bor 4\% C & 6.04 & 0.05 & 37.1 & 31.6 & 5.61 & 33.6 & 0 & 0 & 0.15 & 114 \\
\hline Black Pine 8 \% C / crni bor 8\% C & 4.70 & 0.04 & 38.0 & 31.8 & 4.18 & 32.6 & 0 & 0 & 0.27 & 112 \\
\hline Aspen wood / drvo jasike & 3.66 & 3.91 & 151 & 10.9 & 6.20 & 23.2 & 4.67 & 14.0 & 15 & 232 \\
\hline $\begin{array}{l}\text { Aspen pulp control } \\
\text { kontrolni uzorak pulpe od jasike }\end{array}$ & 0 & 0.40 & 101 & 1.66 & 1.34 & 31 & 0 & 0 & 1.01 & 137 \\
\hline Aspen 4 \% A / jasika 4\% A & 0 & 0.31 & 100 & 1.61 & 1.09 & 29.3 & 0 & 0 & 1.76 & 135 \\
\hline Aspen 8 \% A / jasika 8\% A & 0 & 0.35 & 107 & 1.91 & 1.19 & 29.3 & 0 & 0 & 2.85 & 143 \\
\hline Aspen 4 \% B / jasika 4 \% B & 0 & 0.41 & 105 & 1.95 & 1.26 & 31.2 & 0 & 0 & 2.42 & 142 \\
\hline Aspen 8 \% B / jasika 8\% B & 0 & 0.43 & 106 & 1.99 & 1.19 & 25.9 & 0 & 0 & 5.28 & 141 \\
\hline Aspen 4 \% C / jasika 4\% C & 0 & 0.30 & 97.4 & 1.66 & 1.10 & 29.5 & 0 & 0 & 1.78 & 132 \\
\hline Aspen 8\% C / jasika 8\% C & 0 & 0.35 & 96.3 & 1.62 & 1.37 & 26.8 & 0 & 0 & 2.97 & 129 \\
\hline
\end{tabular}




\section{CONCLUSIONS}

\section{ZAKLJUČAK}

The results of this study showed that using of A, $\mathrm{B}$, and $\mathrm{C}$ in kraft pulping provides various benefits. The addition of $8 \% \mathrm{~B}$ to the cooking liquor of both species resulted in higher screened and total yield increases compared to A and C. Also, the addition of $4 \%$ $\mathrm{A}$ and $8 \% \mathrm{~B}$ to the cooking gave the best results in European black pine and European aspen, respectively, in terms of paper strength properties. Especially, the addition of $8 \% \mathrm{~B}$ significantly increased the pulp strength in European aspen samples.

Similar results were observed in the chemical composition. In European black pine kraft pulp, 8 \% B increased the stability of Xylose, Mannose and 4-0MeGlcA units compared to control samples. The addition of $8 \% \mathrm{~B}$ and $8 \% \mathrm{~A}$ also has a positive effect and enhanced the amount of sugar units and total amount of hemicelluloses in aspen. As mentioned before, this positive effect directly influenced the strength properties of handsheets.

The boron compounds used in this study are cheaper than other digester additives, such as $\mathrm{NaBH}_{4}$ and AQ. After some additional studies e.g. using of these boron compounds with other lignocellulosic materials, their effects on recovery cycle and recoverability of boron compounds, these boron compounds (A, B and C) can be used in pulp mills.

\section{Acknowledgements - Zahvala}

This research was supported by the Scientific and Technological Research Council of Turkey (TUBITAK, Project Number: 113O146). The authors are especially thankful to TUBITAK for financial support.

\section{REFERENCES}

\section{LITERATURA}

1. Akgul, M.; Copur, Y.; Temiz, S., 2007: A comparison of kraft and kraft-sodium borohydrate brutia pine pulps. Buildin and Environment, 42 (7): 2586-2590. https://doi.org/10.1016/j.buildenv.2006.07.022

2. Akgul, M.; Tozluoglu, A., 2009: A comparison of soda and soda-AQ pulps from cotton stalks. African Journal of Biotechnology, 8 (22): 6127-6133. https://doi.org/10.5897/AJB09.301

3. Atik, C., 2002. Soda-AQ pulping of okra stalk. Cellulose Chemistry and Technology, 36 (3-4): 353-356.

4. Aurell, R.; Hartler, N., 1963: Sulphate cooking with the addition of reducing agents. Part III. The effect of sodium borohydride. Tappi, 46 (4): 209-215.

5. Bai, L.; Hu, H.; Xu, J., 2012: Influence of configuration and molecular weight of hemicelluloses on their paperstrengthening effects. Carbohydrate Polymers, 88: 12581263. https://doi.org/10.1016/j.carbpol.2012.02.002

6. Danielsson, S., 2007: Xylan reactions in kraft cooking. Process and product considerations. Doctoral Thesis. Royal Institute of Technology, School of Chemical Sciences and Engineering, Stockholm.

7. Diaconescu, V.; Petrovan, S., 1976: Kinetics of sulfate pulping with addition of sodium borohydride. Cellulose Chemistry and Technology, 10 (3): 357-378.
8. Eti Mine, 2013: Strategic plan for 2015-2019. http:// www.etimaden.ov.tr/files/files/document/files/Stratejik_ plan 2015 2019.pdf

9. Forsström, J.; Torgnysdotter, A.; Wãgberg, L., 2005: Influence of fiber/fiber joint strength and fiber flexibility on the strength of papers from unbleached kraft fibers. Nordic Pulp and Paper Research Journal, 20 (2): 186-191. https://doi.org/10.3183/NPPRJ-2005-20-02-p186-191

10. Gulsoy, S. K.; Eroglu, H., 2011: Influence of sodium borohydride on kraft pulping of european black pine as a digester additive. Industrial \& Engineering Chemistry Research, 50 (4): 2441-2444. https://doi.org/10.1021/ie101999p

11. Gülsoy, S. K.; Kılıç Pekgözlü, A.; Aktaş, A. C., 2015: Utilization of the pomegranate tree (Punica granatum L.) in the paper industry. Turkish Journal of Agriculture and Forestry, 39: 295-299. https://doi.org/10.3906/tar-1404-105

12. Gümüşkaya, E.; Erişir, E.; Kirci, H.; Misir, N., 2011: The effect of sodium borohydride on alkaline sulfite-anthraquinone pulping of pine (Pinus pinea) wood. Industrial \& Engineering Chemistry Research, 50(13): 8340-8343. https://doi.org/10.1021/ie200633z.

13. Hartler, N., 1959: Sulphate cooking with the addition of reducing agents, Part 1 . Preliminary report on the addition of sodium borohydride. Svensk Papperstidning, 62 (13): 467-470.

14. Hu, G. C.; Fu, S. Y.; Liu, H., 2013: Hemicellulose in pulp affects paper properties and printability. Appita Journal, 66 (2): 139-144.

15. Istek, A.; Ozkan, I., 2008: Effect of sodium borohydride on Populus tremula L. kraft pulping. Turkish Journal of Agriculture and Forestry, 32: 131-136.

16. Jakate, D. N.; Rao, G. V.; Swamy, V. S. R.; Swamy, C. V.; Gopichand, K.; Sarma, G. S. R. P., 1981: Soda-AQ pulping of rice straw. Tappi Journal, 64 (6): 124-125.

17. Jiang, J. E., 1994: Extended modified cooking of southern pine with polysulfide - effects on pulp yield and physical-properties. Tappi Journal, 77 (2): 120-124.

18. Kamyar, S.; Othar, K.; Rudolf, P., 2014: Comparison of MEA/AQ, soda and soda/AQ pulping of wheat and rye straw. Industrial Crops and Products, 52: 603-610. https://doi.org/10.1016/j.indcrop.2013.11.014

19. MacLeod, M.; Radiotis, T.; Uloth, V.; Munro, F.; Tench, L., 2002: Basket cases IV: Higher yield with Paprilox (TM) polysulfide-AQ pulping of hardwoods. Tappi Journal, 1 (8): 3-8.

20. Manji, A. H., 1996: Kraft pulping of coastal softwood from British Columbia using AQ and a digester additive. Tappi Journal, 79 (10): 147-152.

21. Molin, U.; Teder, A., 2002: Importance of cellulose/ hemicellulose-ratio for pulp strength. Nordic Pulp \& Paper Research Journal, 17 (1): 14-19. https://doi.org/10.3183/NPPRJ-2002-17-01-p014-019

22. Paananen, M.; Sixta, H., 2015: High-alkali low-temperature polysulfide pulping (HALT) of Scots pine. Bioresource Technology, 193: 97-102. https://doi.org/10.1016/j.biortech.2015.06.075

23. Pekkala, O., 1982: On the extended delignification using polysulfide or anthraquinone in kraft pulping. Paperi Ja Puu-Paper and Timber, 64 (11): 735-741.

24. Santos, A. J. A.; Anjos, O. M. S.; Simões, R. M. S., 2008: Influence of kraft cooking conditions on the pulp quality of Eucalyptus globulus. Appita Journal, 61 (2): 148-155.

25. Schwikal, K.; Heinze, T.; Saake, B.; Pulps, J.; Kaya, A.; Esker, A., 2011: Properties of spruce sulfite pulp and birch kraft pulp after sorption of cationic birch xylan. Cellulose, 18: 727-737.

https://doi.org/10.1007/s10570-011-9526-y 
26. Shin, N. H.; Stromberg, B., 2006: Xylan's impact on eucalyptus pulp yield and strength - Myth or reality? In: Workshop on Chemical Pulping Process, 1.

27. Sundberg, A.; Sundberg, K.; Lillandt, C.; Holmbom, B., 1996: Determination of hemicelluloses and pectins in wood and pulp fibers by acid methanolysis and as chromatography. Nordic Pulp and Paper Research Journal, 11: 216-219. https://doi.org/10.3183/NPPRJ-1996-11-04-p216-219

28. ***TAPPI Standart Test Method T-275 Screening of Pulp, 2002.

29. ***TAPPI Standart Test Method T-200 Laboratory Beating of Pulp, 2001.

30. ***TAPPI Standart Test Method T-236 Kappa number of Pulp, 1999.

31. ***TAPPI Standart Test Method T-210 Sampling and Testing wood pulp shipments for moisture, 2003.

32. ***SCAN-CM 15-62, Viscosity of cellulose in cupriethylenediamine solution (CED), 1962.

33. ***ISO.5267-,1 Pulps - Determination of drainability Part 1: Schopper Riegler method, 1999.

34. ***ISO 5269-2 Pulps - Preparation of laboratory sheets for physical testing - Part 2: Rapid-Köthen method, 2004.

35. ***TAPPI Standart Test Method T-402 Standard conditioning and testing atmospheres for paper, board, pulp handsheets, and related products, 2003.
36. ***TAPPI Standart Test Method T-494 Tensile properties of paper and paperboard, 2001.

37. ***TAPPI Standart Test Method T-403 Bursting strength of paper, 2002.

38. ***TAPPI Standart Test Method T-414 Internal tearing resistance of paper, 1998.

39. ***TAPPI Standart Test Method T-525 Diffuse brightness of pulp, 2002.

40. Tavast, D.; Mansoor, Z.; Brannvall, E., 2014: Xylan from agro waste as a strength enhancing chemical in kraft pulping of softwood. Industrial \& Engineering Chemistry Research, 53 (23): 9738-9742. doi: 10.1021/ie5006806.

41. Tutus, A.; Ates, S.; Deniz, I., 2010: Pulp and paper production from Spruce wood with kraft and modified kraft methods. African Journal of Biotechnology, 9 (11): 16481654.

\section{Corresponding address:}

Assoc. Prof. AYBEN KILIC PEKGÖZLÜ, Ph.D.

Faculty of Forestry, Bartin University

Bartin, 74100 TURKEY

e-mail: akilic@bartin.edu.tr 